\title{
A Journey from Zeila to Lake Rudolf
}

\section{Author(s): James J. Harrison}

Source: The Geographical Journal, Vol. 18, No. 3 (Sep., 1901), pp. 258-275

Published by: geographicalj

Stable URL: http://www.jstor.org/stable/1775132

Accessed: 05-06-2016 05:25 UTC

\section{Your use of the JSTOR archive indicates your acceptance of the Terms \& Conditions of Use, available at}

http://about.jstor.org/terms

JSTOR is a not-for-profit service that helps scholars, researchers, and students discover, use, and build upon a wide range of content in a trusted digital archive. We use information technology and tools to increase productivity and facilitate new forms of scholarship. For more information about JSTOR, please contact support@jstor.org.

The Royal Geographical Society (with the Institute of British Geographers), Wiley are collaborating with JSTOR to digitize, preserve and extend access to The Geographical Journal 
water, fully 25 miles in length by 10 in width, filled with fish of all the kinds common to Northern Canada. To the east and south of this lake a low range of hills, the Eastlake mountains, rise to a height of about 1300 feet. A view from the top of this range showed a tree-covered country dotted with lakes in all directions as far as the eye could reach.

Near Dawaso-necha lake we were fortunate enough to meet some Dogrib Indians, who agreed to guide us across the height-of-land to Great Slave lake. Crossing the low swampy ridge, we reached the waters of Summit lake, which empties by the Marian and Petitot rivers into Lake Marian, the northern expansion of the Fort Rae arm of Great Slave lake. We descended the Marian to its junction with the Petitot river, making numerous portages to avoid rapids and falls. We passed down the Petitot river to Lake Marian, whence our journey across the lake to Fort Rae, the most northerly point in this direction, was a comparatively easy one, but attended with some danger owing to the lateness of the season.

All the country south of Great Bear lake, almost as far east as the Coppermine, is fairly well wooded. The Dogrib Indians who inhabit this region are a kindly, good-natured tribe, superior to their Hareskin neighbours to the north. The numerous lakes teem with fish, which with waterfowl formed the chief food-supply of my party after leaving Great Bear lake. Moose and bear are common, while caribou at certain seasons of the year are still plentiful; but year by year these animals, which formerly inhabited the whole country east of the Mackenzie, have been pushed gradually northward, so that places which they visited as recently as six years ago, know them no more. Every year the Indians and Eskimo kill thousands of them for their tongues alone, and even for the "sport" of killing them, so that there is a probability in the near future of this beautiful and useful animal sharing the fate of the North American buffalo.

\section{A JOURNEY FROM ZEILA TO LAKE RUDOLF.*}

By JAMES J. HARRISON.

THE object of our expedition was to carry a complete survey through the Hawash valley to Lake Rudolf, and if possible across to the Nile, at the same time combining a sporting trip in which attention was to be directed to the beasts and birds of the countries visited. On November 5, 1899, we landed at Aden, our party consisting of Mr. A. E. Butter, Mr. P. G. Powell-Cotton, Mr. W. F. Whitehouse, and myself. As surveyor we had Mr. Donald Clarke, who had already had some twenty years' experience of surveying work in different parts of Africa; while Mr. R. Perks went as taxidermist. A few hours' delay to make final

* Map, p. 352. 
arrangements with Messrs. Cowasjie Dinshaw found us and stores on board the Woodcock, another fourteen hours landing us at Zeila on November 9, 1899.

It took us five days' hard work to repack and arrange our loads, engage boys (who asked enormous wages), and collect more transport. We were lucky enough to induce Mohamed Hassan, a Somali boy, to go as our headman, he having already done much of the country with poor Captain Wellby. Besides speaking good English, Abyssinian, Galla, and innumerable other tribal languages, he proved himself to be quite the hardest-working man I ever met. We engaged a splendid lot of boys, in all about 61 , chiefly those accustomed to long trips, most having been with Lord Delamere, Dr. Donaldson Smith, Captain Wellby, or Mr. Cavendish. We knew at the outset that our journey was undertaken at the worst possible time, owing to the unprecedented two years' drought which had extended over the whole of East Africa to the Nile. Our transport, to begin with, was sixty camels (twelve for water) purchased, and twenty hired to Gildessa, but the latter were afterwards replaced by bought ones, for which we sent back to Berbera, they following us loaded with rice. To Gildessa our route is fairly well known. Owing to drought we had to make some long marches, doing 164 miles in twelve days-an average of $13 \frac{1}{2}$ miles a day-mostly between the hours of 2 and 9 a.m.

The country varies from the hard sandy plain covered with rough short scrub to undulating hills covered with rocks and boulders. Grass, of course, was out of the question, but our camels picked a living among the mimosa trees. For our ponies we carried a little corn and fodder, but on reaching Gildessa we owned another fortnight of such country would have ruined our transport.

The game we found consisted of Semmering's gazelle, Pelzeln's gazelle, Waller's gazelle, Beira antelope (in the high Marmar mountains at Aroweina), the beautiful lesser koodoo, greater koodoo, and wart-hog. On shooting the latter, how one hated Somali boys and their Mohammedan religion! for nothing would induce them to touch the animal, so all the loading, bringing into camp, skinning, drying, and even packing every day for the march, had to be done by the white man. More than this, any sack, rope, or knife touched by the poor pig was defiled, and had to be destroyed. Smaller animals included the beautiful little dik-dik, lynx, jackal, fox, hare, with numerous guinea-fowl, bustard, eagles, and vultures. One of the latter measured 110 inches from tip to tip of wing, standing 42 inches high, while the span of the claws was $9 \frac{1}{2}$ inches.

Between Hensa and Lasman the country is all volcanic, and terribly hard marching for camels. Water had to be carried nearly every other march, all the streams being dry, and most of the Somali wells too. At Aroweina the wells are 28 feet deep in the river-bed, and yet there is hardly any water. On November 22 we camped in the dry bed of a 
stream, Beja Kaboba, just under a conical-shaped hill with a small stone fort flying the Abyssinian flag. We very soon had a state visit from the governor and garrison, consisting of an outpost of four men. Having fired numerous salutes, we entered into conversation over a glass of brandy, and found we were expected, notice of our coming having been sent down by the Emperor Menelik. In this district we found lesser koodoo fairly plentiful. Here we unfortunately began losing our camels, no doubt owing to their eating that scourge of a plant called "gumbot," which is poisonous. Having got our caravan into fairly good working order, we began the daily task of drilling our retainers, 50 of whom were armed with government rifles from Aden. On November 26 we reached Gildessa, escorted to our camping-place by the whole population. After lunch, our worthy friend the Shum "Alto Zavike" came in state to call. Nothing could equal the kindness we received while staying here two days: presents of sheep, goats, honey, milk, eggs, bread, and frewood came in daily. To our great joy we found four good mules awaiting us, kindly sent down by Colonel Harrington, also letters saying the Emperor had given us leave to travel by a new route through the Hawash valley, and would be pleased to see us at Adis Abbeba. Being short of transport, we left eighteen loads of durra and rice to follow with hired camels when Mohamed should come with our second detachment. We could only buy six donkeys and a few sheep and goats (the latter for milk).

On November 28 we left Gildessa, accompanied by a large following, our road lying through thick scrub, while we wended our way by sheep-tracks between high ranges of hills, camping at a place called Odah. During our march we crossed two running streams, the first running water since leaving the coast. These streams join two other rivers-the Gildessa and Odah; but following them down some 20 miles, we found them disappear through running out and sinking into the earth, a rather common occurrence in Northern Africa. For some days our course lay due west along the foot of a lofty range of broken mountains, called the Kobul hills. I climbed these one day after large koodoo. The rocks were awful, evidently all due to very recent volcanic action. Our camels here looked very bad; so, resting a day, we made a big koodoo into strong soup, and gave each camel a good drink, which seemed to effect a wonderful change. Along this valley we found several nice streams running. On December 4 we camped at a series of water-holes called Ulfulu, around which were gathered hundreds of camels, goats, and sheep. Here, also, we had to sit and undergo at least an hour and a half of native war-dances, given by three neighbouring chiefs and forty of their followers clad in full war-paint. Another march brought us to the river Herrar, on the banks of which we found some lovely trees to camp under. Here our Gildessa guides and twelve hired camels left us, the country ahead 
belonging to a powerful and independent chief called Tumbacha. A two hours' march brought us to his village called Korta, a short distance from which we discovered what had once formed two good lakes, but was now only a huge marsh overgrown with dense reeds. The chief, a most unprepossessing individual, paid us a long visit. $\mathrm{He}$ began by demanding absurd presents before letting us pass, and after hours of talking, he and his retainers all left in a by no means friendly manner. Having no thorns with which to make a zereba, we stored our baggage as a rampart, doubled all sentries, and served out ball cartridge. This chief has for years caused the emperor great trouble, fighting his people and raiding caravans; so lately he has been kept quiet by the payment of an annual sum. For this reason we were most anxious to part friends, especially as our second detachment of loaded camels was behind. We moved on for two days, when, finding some excellent grass, we determined to camp, sending back eight armed men to help our rear convoy in case of trouble. Before they arrived, Tumbacha had beaten two of our men and tied them up until they promised to give him a camel-load of rice and two bales of cloth. We were thankful to see the rest march into camp, but it was hard to prevent our boys from going back to fight and burn the village.

On December 10 we reached a small lake called Odah. From the contour of the land, which showed the well-marked dip of the old shore, this lake had once been a very large sheet of water. Here we had some good duck and geese shooting, and I was also lucky in getting an "ant-eater," a small but very rare animal. A lofty mountain range called Garamaldit stretched many miles east and west just south of our course. During our next day's march my mule ran away for the third time, coming to grief in a fox-hole, but neither of us was much the worse apart from some bruises. I had hopes that this fractious animal would settle down with careful handling, but after this I christened him "Oom Paul," as I had no hopes of his mending his ways until one of us had come to grief. On December 12 we crossed a river called Mukla, rising in the lofty mountains to the south, of which the highest is known as Mount Assobat. Rising ground all the 13th brought us to Dunkaga (3770 feet), the 14 miles having been done under terrible heat. Next day we made a forced march of nine hours, doing 18 miles over an endless plain called Aleaduga, on which we saw thousands of camels feeding, and also met with our first zèbra, oryx, and hartebeest. We finally camped at Bilen hot springs. The temperature of the water was $110^{\circ}$, springing up in a pond about 30 yards across, clear as crystal. We enjoyed an evening bathe here, while just at dusk the banks all round would be covered with sandgrouse. Half a mile further on this water ran into a huge swamp some 2 miles long by 1 wide, covered with dense rushes 10 feet high. In this place we located the only herd of buffalo met with until we reached the lower end of Rudolf. We stayed 
three days, trying every means which might enable us to shoot a specimen, but without luck. We tried machans at night; we tried walking: round the outskirts in bright moonlight, and nearly with success, but just after seeing some feeding at about 2.15 a.m. on December 17, an eclipse of the moon took place, and the darkness spoilt our stalk. A most curious fact about the eclipse was, the shadow started covering the moon from the right top corner; on clearing things were exactly reversed, light first appearing on the left bottom corner, and the last dark spot clearing from the right top. Mr. Whitehouse noticed the same from a place 3 miles distant. We attempted to follow the buffalo on their narrow tracks, up to the waist in awful slime and green mud, the accumulation of centuries, judging by the smell. As a last resource we organized a grand drive, while we took likely stands in main tracks. The expenditure of five hundred blank cartridges and much shouting only resulted in two of our beaters getting tossed, luckily with no serious injury; so we had to leave Bilen beaten, but vowing vengeance against the buffalo should we ever come that way again. Round the swamp we found our first lion-spoor. Building a zereba with our lion donkey tethered outside resulted only in quite the most unpleasant night possible. Oh, the mosquitoes! Their size and avidity for the Anglo-American blood! Several side trips gave us a good idea of the country. About 5 miles north-west we came across the bed of the Hawash river, just across which were three extinct volcanoes. A few miles further we discovered a lake called Lihadu, fed by the Marion river running from Abyssinia, while the outgoing river, the Arthso, is said to join the Hawash some miles further north. The river here was obstructed a good bit by sandbanks, on which were basking numerous crocodiles. A small lake of fresh water we called Kemp lake, numerous small streams from the Dofat valley running into it, though we could find no outlet for its waters.

On December 19 we reached the much-talked-of Hawash river, a fine broad stream of 90 yards in width, deep, with a fast-flowing current; this river is another which is said to run out and disappear some 70 miles further north-east; such a volume of water, one could hardly believe it. Here our Berthon boat became decidedly popular, especially as crocodiles abounded. We found at this camp oúr first fresh elephant-spoor, and, being keen to procure some ivory to take up as a present to the emperor, we all separated and entered a 3-mile patch of dense African jungle; huge prickly aloes, enormous cactus with long sharp points, and a tall feathery plant like privet, made up a safe asylum from ordinary mortals. Very few minutes sufficed to turn hunters into hunted. No. 1, a cow, charged down on us. Jumping aside, I killed her as she rushed on my shikaree, not 4 feet from him. Hardly had we struck the spoor of another lot, when a young bull suddenly bore down on me; however, a lucky forehead-shot laid him low. While 
skinning one of these heads, the whole place seemed alive with elephant crashing towards us. Seizing my rifle, I ran ahead to try and cut off the troop, when suddenly a line of over forty elephant broke cover, about twenty-five in the first line jammed together like a cavalry regiment charging. Being only 20 yards from me when they appeared, with the centre bearing directly down on one, I own to feeling they had the best of me, I saw my only chance was killing a flank one; in a second I dropped the left-hand one, which, falling inwardly, inclined the whole troop a little to the right. Within 10 yards I fired my remaining barrel, dropping another, causing still further deflection to the right; another second the flank one on the left rushed past, almost knocking me down. I felt thankful for such a lucky escape, and blessed my new $\cdot 450$ cordite rifle by Rigby, which had done such good work, five elephant in six shots unquestionably proving its value. I found, on returning to camp, Whitehouse and Butter had both undergone similar experiences, and I felt bound to apologize for introducing them to their first elephant-such elephant, and in such a jungle! We stayed at the Hawash river camp till Christmas Day, spending Christmas Eve again sleeping out for lion. Early Christmas morning we moved, cutting off a big bend of the river, and as we approached the banks we were a little alarmed to see scores of armed warriors galloping in from all directions. We at once took the precaution to form up and wait for stragglers. In the mean time we found they were only a large party of Gallas hunting; they were fine men, and splendidly mounted, but entirely nude, excepting a few who wore a bit of skin on the shoulders. Having never seen a white man before, they exhibited much astonishment at our boots, thinking they were our feet with only one toe! The river here was 5 feet deep, with a strong current; despite crocodiles, Clarke took his clothes off and swam over. A few hundred yards and we again had to cross the Kassam river, banks 30 feet high and very steep. We decided to camp on the bank at a place called Lamafun, all around being thick bush. From our camp we had a fine view of Mount Assobat due East, while a fine-looking pile to our west obtained the name of Clinton range. We prepared a sumptuous Christmas repast that evening, ending up with plum-pudding carried for the occasion; while a bottle of champagne was taken from the medicine store (no liquor being carried except as medicine), in which the toast of home and absent friends was drunk. Retiring to bed at 10.30 , my friends did not love me when at 1.45 a.m. the morning trumpet sounded, but on a long trip the camels must be considered before anything else. A short march brought us once more on to the main track from Harrar to Adis Abbeba, and it seemed funny to suddenly run against a telephone wire, which the emperor has up to the capital from Harrar.

On December 27 we again reached the banks of the Kassam river, the road crossing many deep ravines, but beautifully shaded by large 
mimosa and other trees. We halted under some big thorn trees at a place called Tadechamalka, and at once set all hands to work making a large zereba, as we intended giving the camels a well-earned rest while we journeyed up to pay our respects to the emperor. Clarke stayed behind in charge of the camp, glad to have time to go over all his work, and complete his mapping up to date. With about six boys and Mohamed we started for our 100-mile ride, camping at Choba, alt. 4800 feet. At Balge, situated on a high plateau over 2000 feet above the country below, we began to feel the cold terribly, added to which it rained daily. Passing Chaffe Dunsa, and Akaki, alt. 7800 feet, we at last arrived at the capital on January 1, proceeding direct to the English compound, where we were most warmly welcomed by Colonel Harrington, who not only supplied us with numerous tents, but made us his guests for ten days, during which we had a most delightful time. On New Year's Day we all dined with the Italian minister. On January 5 we were received by the emperor, who was most kind, and promised every assistance through his country to Rudolf. We bought five fresh mules, two Abyssinian horses, and a flock of 100 sheep. On Sunday, January 7, being their Christmas Day, the emperor most kindly asked us all to dine in the huge hall called Abderash, a building about 190 feet long, 90 feet wide, and 35 feet high. All the ministers, ras, and principal generals were present on the raised daïs round the throne, while in the body of the hall about 30,000 soldiers were fed in two detachments. Our menu was as follows :-

Milk and rice soup. Kabobs of meat and potatoes. Omelette and herbs. Mince and artichokes. Fillets of beef and radishes.

Kabobs of mutton and cabbage. Fried brains. Fried mince and maccaroni. Smoked beef and lettuce. Brown rolls and flat bread. Coffee.

Honey beer. French claret. Arrack. 12-year-old teg and Epernay champagne.

After dinner we shook hands, and, through an interpreter, thanked his Majesty for so much kindness. He replied, "May the Lord keep you well, and may you return safely to your own country. May you have good shooting and a pleasant journey through my country."

On January 9 we all turned out to meet the emperor for a trial hunt with hounds, and also with two horses sent by her Majesty the Queen to the emperor. We were lucky enough to find and kill a jackal, which much pleased his Highness and the thousands who escorted him. The emperor then returned to the English compound, where hospitality was dispensed by Colonel Harrington. On January 10, accompanied by Mr. Baird, we bade our kind host farewell, agreeing we had never spent a more enjoyable ten days. We reached our main camp in three days, and found many boys down with fever. Here we remained four days, packing all our trophies to send back to the coast, getting rid of all useless baggage and cutting our men down to fifty. Mr. Powell Cotton had lately decided to leave the party 
and return to Adis and work north after ibex, of which I since hear he obtained three specimens. On January 18 we made another start, passing by more of those wonderful boiling springs. A few miles further on, baving left our course to climb some high ranges, we suddenly came on the ruins of a large town and fort called by the natives Hallam, said to have been built about 900 A.D. by the emperor Zarakob, who was defeated by Granya. It is a wonderful place, laid out on the summit of a lofty hill, the walls, 3 feet thick, of loose piled stones, all now levelled to about 3 feet in height. One could still trace all the foundations of the houses, with streets winding in and out. The town covered a space one mile long by half a mile broad. On January 19 we camped at the Mathara lakes. Though not far apart, the large one was quite salt, while the small one, Edith lake, was fresh. We had some terrific climbing in an attempt to get across to a small mountain for survey work. Recent volcanic eruptions had simply strewn the whole country with enormous blocks of lava, while masses of solid rock of all sizes, up to 15 feet square, had been thrown up and scattered thick as hailstones. I cannot imagine a rougher climb in the world, and only two got through, though many started. This march left the fine pile of the Fantali mountains just behind us ; for weeks their highest peak had been one of our survey points. A long march next day brought us to the Hawash river again. This country having never been visited by white men, we were again the objects of great interest. Though the valley afforded good grazing, it had very few inhabitants, while the south bank was densely covered with mimosa bush. The whole country abounded with the camel poison tree, which alone entailed endless labour and anxiety.

On leaving Oresa we found the first cultivation-peas, cotton, maize, and barley being grown, while the district was densely populated with Arusi Gallas, occupying large villages called Oresa, Wargi, Korri, and Wagia; but even here drought was beginning to tell its tale. We shot two hippo while camping on the river; and encountered an Abyssinian gentleman, who, having nothing else to sell us, tried to sell his wife. After repeated attempts, he and the good lady, looking crestfallen at not even raising a bid, proceeded on their journey. Our spare time all along this valley was fully occupied with prescribing for every kind of ailment; the chief being bad eyes, for which, unfortunately, we were quite unprepared. We had now for some time a splendid view of that grand mountainous mass called Zakwala, 10,000 feet above sealevel, this and Fantali being of great assistance in our survey work. We passed a small sweet-water lake with no name, but covered with wildfowl, arriving at Gogo near Lake Buffa on January 26. Here we rested our transport for a few days while we made a side trip to ascend Zakwala, some 22 miles distant. Leaving our mules at the foot of the mountain, we began our hard task. At an altitude of 8500 feet we

No. III.-SFPTEMBER, 1901.] 
stopped for lunch, and admired the grand view. Butter and Clarke, both born mountaineers, pressed on to the summit, which had once been an old crater, but now forms a pretty little lake, called by us Butter lake, about three-quarters of a mile in circumference. Rising all round from the water's edge are the sides of the crater, in places 600 feet in height. On the lake dwell a priest and several hermits, while on the eastern slopes are several villages ensconced in crevices of the rocks. The hill is considered holy, and boasts of three churches, one in ruins, while the whole place rings with superstition. For instance, the hermits go daily to pray at a curious chasm in the rocks, the legend recording how in olden days a pious hermit ascending the hill met the devil, whom after a severe struggle he conquered; so, founding a chapel, he settled down there, people coming from far and wide to cure disease by bathing in the lake. The whole country round was under the rule of Fiterauri Apta Mariam, who has the right to administer justice for all offences excepting murder, which rests with the emperor. As usual, the women do most of the work, weaving a great deal of the cheap calico, threshing out corn with curious flails, while in places they carry all the water on their heads for miles.

At Gogo we said good-bye to Baird, from whom we much regretted parting, for a more cheery companion or better sportsman it would be hard to find. We found sickness rife in camp, twelve boys being bad with fever. It is wonderful how food and no work plays havoc with a whole caravan. On February 1 our boys were all looking out unxiously for the new moon, which heralded their Christmas Day (making the third we had kept) and ended Ramadam, their month of fasting. We got fine views of Mount Sitala to the south, also the smaller peak Arbora. We camped at Gafartha, in the middle of the Bugra plain, covered with wretched grass and half-dead bush-no water. A side trip of a few miles brought us to three small fresh-water lakes, which we christened Queenie, Gladys, and York lakes. Another 12 miles took us across the river Maki, which feeds Lake Zwai. The grass round here had been lately burnt, making us terribly black and dirty. Next day we reached the shores of Lake Zwai, 5400 feet-a fine sheet of water about 25 miles long, full of hippo and wild-fowl. Here we had very bad luck, our camels having the previous day got to the gumbot tree. By this we were delayed a week, during which we were kept in terrible suspense. All the camels were affected, several went mad, others were unable to get up, and it really looked a hopeless case, for we had no chance of replacing them. We promptly killed two sheep, and with boiled durra drenched them twice a day with strong soup; we also tried firing them. We lost a pony here from horse-sickness. Luckily, our camp was among countless herds of game-hartebeest, Grant's and reed bucks chiefly-so we had no need to consume our stores. The natives belong to the Waiyu tribe of the 
Arusi Galla-a good-looking lot of people, especially the women; one sees among them good noses, no thick lips, but good features altogether. The men wear clothing, armlets of ivory or copper, necklace of beads, and feathers in the hair; they are armed with clumsy illfashioned spears, also a huge chopper-like knife with a round end rather like an Indian cookie. Terrific thunderstorms visited us night and day. We were lucky in being able to purchase twenty-five really good donkeys ; so on February 10, finding forty-nine camels better, though very weak, we again moved on. I estimate that, through our boys' carelessness, the poison cost us twenty good camels-a serious loss. To the west Mount Gobeha stood out, a notable landmark above the dense bush and forest covering all this country. Most of the inhabitants had never seen a camel ; imagine their fear and astonishment, while their ponies and mules simply went mad and bolted. We next passed Lake Horai, to the east of which lies Lake Seveta; during the rains both join and form one large water. The river Suksuk joins Zwai and Horai. Another river joins Horai and Lamina, while Mount Alga divides the two waters. A curious thing was that the lake-water, of a pretty green colour, though quite sweet, refused to be forced through our filters; close by the Gidu falls the water was brick-red. The Tuka Gallas are all great hunting people, hardly doing anything else; they inhabit the western shore of Horai.

Travelling along the foot of the Kambata range, we crossed many running streams, and a country densely populated, the chief tribes being Adarri, Waragi, and Gurage; all seemed well-to-do Galla. We had now to leave the low country and face the steep hills of Ulamo. After two days' incessant climbing up and down ravines, we emerged on the fertile hill on which the chief village of Ulamo is situated. How pretty all the country looked on these hillsides, green with young grass and many kinds of timber; hundreds of kraals, each in its own little plot, surrounded by banana and palm trees; while cotton, limes, ginger, and a vegetable called "godaris" grew in profusion! The mountain-sides to the topmost peaks were cultivated, the bright red patches of soil glistening in the sunshine. Many sorts of lilies and other flowers, besides innumerable gay-plumaged birds, met our view on every side. Marketplaces abounded-every two miles-and thousands of natives collected daily at each. We camped near Mount Dalbu, 6700 feet, the mountain itself towering to a height of 10,400 feet. To the west stood out a fine range of hills with three peaks, which we called Brandesburton range; while further south an unnamed mass of hills was called Whitehouse range, a continuation of which, a mass of mountain much broken up with deep ravines, was christened York range, with a notably high peak, James peak. We here found quite a new currency-thin bands of iron 2 feet long, 1 inch wide, sixteen of which go to the Abyssinian dollar; they are called "dorma." The shum being absent, his headman 
brought us abundance of presents, which, of course, we returned by other gifts. Next day, February 22, we got our first view of Lake Margherita. I forgot to mention at Ulamo (which, according to Captain Wellby, is "devil-haunted") we tempted Providence by taking all our meals in the presence of hundreds of spectators, but with no ill effect. The legend runs that any one seen eating by Ulamo people goes mad; what we were nearly prevented from doing, was eating at all, owing to the countless swarms of bees which invaded our table.

We next traversed the district of Baroda. Rain every day made the roads almost impassable; climbing up and down mountains 5000 feet in a march almost broke one's heart, and sereral camels sank down to rise no more. At Baroda a priest and his acolytes joined us, and, clad in their vestments with coloured umbrellas, accompanied us on a 7 -mile march ; singing and chanting, they refused to be shaken off till we halted and unpacked the dollars! On February 27, after terrible hillwork, besides a couple of miles of road over swamp, we were met by Fiterauri Doris's headman, accompanied by 277 natives bearing presents; these were merely for that night's use! But ob, the cold, despite our roaring bonfires! We were 8900 feet up, in thick fog and rain, quite among the clouds. Next morning half our camels could not get up till we had lighted fires all round them and thawed the poor beasts. But our hill troubles were nearly over for the present, 100 natives coming. to carry some of our kit and ease our camels. Next day a deep river, followed by wet and uphill climbing, quite demoralized our caravan. I had gone on ahead, muddy and wet through, and, with only three boys, was dragging along some fifteen weary camels, when, surmounting a hilltop (9400 feet), I suddenly came upon a very pretty picture. Our track lay between two banks, each of which was crowded with people. Fiterauri Doris was there, with all his officers, and 700 soldiers clad in their bright-coloured garments; mounted men were dashing about to keep back the crowds of Gallas, while hundreds of horses and mules with gay trappings were standing about in groups. Of course I had to pull myself together and look my best. After warm greetings, I was led towards a fine mule, possibly a splendid hack when you got on, which I never did. Abyssinian stirrups are 2 inches wide, and what with my shooting-boots, and the mule's kicking and rearing, I never got within 3. feet of the saddle. However, my kind host gave me a more reasonable mount, and the cortège proceeded to the site fixed on for our camp. How I longed for my companions to be with me ! but unfortunately they were behind. The presents were carried by 531 men, women, and children as follows: 181 grass, 146 firewood, 89 bread, 61 ghee (butter), 15 honey beer, 12 honey, 8 butter, 10 grain for ponies, 6 chickens, 2 cows, 2 camels, and basket of eggs. Our presents in return were a sword, revolver, bottle of kümmel, blankets, razors, and scissors. We were most pleased when our kind host 
told us not to load our camels any more among the hills, and sent us about 500 Gallas to act as bearers. During this march we crossed our highest point-just over 10,000 feet, at which level we found, to our surprise, bamboos, blackberries, daisies, tiger-lilies, and trees covered with ferns. It was quite one of our most interesting marches. Arriving at Dincha, our worthy host, Basha Islamani, took us in hand; his presents were 2 cows, 9 sheep, 408 grass, 356 wood, 13 ghee, 7 honey, 153 wine, 97 baskets of bread, 1 grain, 4 curry pepper, 12 chickens, 31 eggs, carried by a grand total of 1093 people. We were again supplied with a fresh relay of porters, one Abyssinian soldier looking after every 10 Galla.

This day's march was more of a slide than anything else, for in less than 7 miles we climbed down 3888 feet; for this porterage we had 800 Galla men. We camped once more on the flat shores of Lake Margherita, or, as the natives call it, Aballa, and at the south end Nai Chaba. A short march brought us to a pretty sheet of water 20 miles in length called by the natives Abaya, and by the Abyssinians Degurabe. We found here a small village, the huts of which are built either on lofty poles in the lake or in the trees on the edge; they are a poor feeble-looking race, living entirely on fish. While camping here we heard of elephant in the dense jungle-grass; we all went off in a body, and, after much walking and continual climbing of antheaps, we located a troop of about twenty feeding towards us. To watch them ten of us crowded on top of one small ant-heap, each holding on to another. We kept quiet, and the wind being right, the troop gradually fed to within 40 yards of us, when, getting our wind and scenting danger, they ranged up in line, with trunks waving, and seven baby elephants close to their mothers' heels. Things began to look unpleasant, so I was deputed to try and scare them. Picking out the largest bull, I dropped him dead with a shot in the brain; this caused the rest to stampede, and released us from what might have been a most awkward and dangerous position had the cows once placed us. However, it was a sight well worth seeing, and one never to be forgotten; but how we cursed our luck to find all our cameras back with the ponies! At Gardula we camped in the middle of terraced gardens, all the hillside being levelled up by thousands of low stone walls; none of the plots are more than 6 feet wide, and yet hundreds of miles are treated in this manner. Here we were courteously entertained by Fiterauri Waldo, who now represents the last Abyssinian outpost; owing to the fearful drought, the more advanced posts at Hammer Koki and on the Omo have all been forced to retire. This officer has 1500 soldiers under his command, who spend all their time killing elephants for the emperor; he told us they alone had sent 1500 tusks to Adis in the last two months, which possibly accounts for the few we found. March 10 to 12 we camped at Godigea, on the river Manta. Here some high hills were called Bererley range, and a particular lofty pile Mount Clarke, 
which our keen surveyor climbed; while due west of Gorso, far down in the big valley which forms the watershed towards Lake Stefanie, we named a pile of mountains Faskally. After traversing the whole district from Gogo and Buffa lake to our present camp, we came to the conclusion that the entire country was once a vast sheet of water, connecting the whole chain of lakes with an outlet at the gorge south-west of Godigea. This part of the valley has formerly been all cultivated in cotton-fields, but it is now neglected and devoid of population. We found our first rhino here, Butter killing one and Whitehouse another; the latter, unfortunately, getting his shikaree, Darod Nur, badly smashed up before he killed it. Having set a broken leg and dressed the other wounds, we sent bim back to our kind friend, Fiterauri Waldo, who nursed him till well enough to send down to the coast.

While waiting, parties of men had tried to find a road for camels to the west. It seemed quite hopeless till at last we discovered the bed of a small rocky stream. Even in this, the rocks twice narrowed to only 3 feet apart, so we had to unload and blindfold all the camels before they would pass through these narrow chasms. The next few days disclosed terrible sights. All along, lately, we had seen single skeletons on our route, but now huge villages, such as Gorso and Dalbana with many others, could not boast of two living people in each. We passed hour after hour through silent cities of the dead, counting six to eight corpses laid together, while inside the kraals you could see the whole family just as they had perished, the last having crawled and dropped almost on the embers of the fire. The few people living were crawling about, eating the young shoots of a certain weed and digging up grass roots. The fearful stories we had heard at Adis Abbeba came back to us, and from what we could gather things ahead looked bad; still, though several times hard pushed for water, so far, among the hills, we had suffered from too much rather than too little. March 15 and 16 still found us travelling through similar sad scenes. We named our last camp in the hills "Desolation," and close to it we suffered a serious loss through one of our best camels, which had carried unchanged from Zeila $280 \mathrm{lbs}$. of rice, falling over a steep precipice while on the march. Falling some 90 feet sheer down, and then rebounding another 50 feet, the poor beast's remains were found fast wedged between two rocks. Our last big climb (6600 feet) we did this march, coming out on the bed of the Galana Sagan river (2700 feet) on March 16. You cannot imagine what getting on to level ground once more meant to us. As we looked back on those lofty mountain ranges, through which we had had to cut our way for three days in dense scrub, we thought of the five weeks spent climbing up and down thousands of feet almost daily, and wondered we had a camel left alive.

We now found ourselves in a valley about 6 miles wide, the Hammer Koki range opposite. This valley used to be the home of huge 
elephants, but, alas! they are about a thing of the past, cleared out by the constant shooting of Abyssinian soldiers, who are now following the ivory right through the Boran country. I procured one big fellow here; unluckily he only had one tusk, $94 \mathrm{lbs}$. in weight when fresh cut out. Here we found existing maps in great error. The big Galana Sagan is shown as running into the Dulei river, whereas it really runs into the valley, and then, spreading out, disappears in all directions, as we found to our cost. The river joining the Dulei further south, and said to be the Sagan, is a different stream rising close by among the mountains on the east, which I called after myself-Harrison range. All these streams were quite dry, though during heavy thunderstorms the whole country was a running sheet of water 6 to 12 inches deep. We had terrible work, our whole caravan being one night and day penned up on two small antheaps. For three days we were stuck fast, losing three or four camels when trying to move only a mile. Following the valley south, we kept a sharp look-out for Lake Donaldson, but found later on we had traversed the whole length of it unknown, all being covered with bush. We concluded that during very rainy seasons a great deal of the land was flooded, but as a lake it was quite undefinable. We now saw ahead, as far as the eye could reach, nothing but a vast extent of ground strewn with shells and heaps of fish-bones. "Stephanie-dry!" we all said; and a thunderbolt in our midst could not have caused more consternation. The sieves had all been burnt, and most of the roots dug up. We afterwards found about two hundred Boran people still living here. They dug up these sieve roots and ground them up, eating them instead of meal. To us it looked like sawdust. We ascertained that the last of Lake Stefanie had dried up about Christmas. We camped near some deep holes dug out to drain the last of the water, but now containing 18 inches of water from the late rains. Terrible was the result of drinking this, for next morning only ten boys were able to move; over forty lay suffering agonies. Luckily, we had used our barrels of rain-water. A move was bound to be made, but half the day had passed before we were loaded up, and then commenced a weary hot march due east for the mountains.

On first reaching the lake we spied some natives, and after an exciting chase two were led in unwilling prisoners; but what a change came over them on finding we were English, and not their dreaded Abyssinian neighbours! They at once guided us to the water-holes, and then went to summon their headmen. From these we learned that most of the inhabitants had died, others having gone up north to the Omo. The worst news was still to come, for on asking if there was good water in Lake Rudolf, they replied there was water, but any one drinking from it died. This seemed a confirmation of all the worst rumours yet heard. Personally, I still felt convinced that a sheet of water over 200 miles long could not be so quickly rendered unfit for 
drinking. Still, it was a cause for much serious reflection. So far, owing to the daily thunderstorms, which the oldest inhabitants said they had never before known to occur at that time of the year, we had reached Stefanie; without them we could certainly not retrace our steps, though we now knew the country; while if they gave out and Rudolf was poisonous! Well, neither happened. On the fourth day we camped on Lake Rudolf, according to our marching distances 45 miles from Stefanie. For the present our maps are not completed further, owing to an error of the chronometer, a thing no one can guard against; the remaining 600 miles of valuable work to Rudolf, and then down its East coast viâ Lake Baringo to Uganda, has to wait till another fixed and corresponding observation (shortly expected to be made) can be obtained, when the rest of the work done will be adjusted in accordance. A curious incident happened here. Mahomed had often told us of a pure white topi he and Captain Wellby had seen and tried to shoot. Sure enough, as we were pitching camp in a heavy storm of rain, our white friend was feeding a mile away among thousands of the ordinary topi. Knowing it to be almost hopeless, I still went out, and at once the whole drove started moving. An hour later Butter came in in great excitement, saying he had shot the white topi. It appears his shikaree had noticed it, and, getting behind an antheap, he was lucky enough to drop it with a very long shot with his mauser as the troop streamed past-splendid luck!

My first act on camping was to send off two camels for water, as the nearer I got to the lake, the greater my anxiety became. I felt ten years younger when the word was passed up, "Water good." On March 31 we left camp early and rode up to visit the Omo at Murle, having decided, if this big river was dry, to work out south by the lake to the Uganda railway. All the thick scrub and timber which should have been alive with elephant, was almost dead, with never a sign of living beast or bird. Passing deserted villages, we came on to the banks of the Omo, and with sad hearts ate our lunch in the middle of the dry stream, while our mules fed on the green luxuriant grass, which had completely covered the whole driedup bed, till it looked more like some green glade in a forest than the important Omo river. Having scouted round the whole country-side in hopes of finding some natives, we returned, and with difficulty selected a single tall thorn tree near Murle. Sending our shikarees up with axe and saw, we dressed all away, leaving only a centre arm, on which we hoisted the English flag; doing so at the request of Colonel Harrington and with the acquiescence of the emperor, to denote the Abyssinian and English boundary-line. Had we been able to discover any inhabitants, we should have hoisted a second flag further north. Needless to say, as the flag went up the whole party sang "God save the Queen," a bottle of champagne having been brought along in which 
to drink her Majesty's health. On carefully examining Rudolf, we found its level had sunk 12 feet during the last year, while in what appeared as three stages (no doubt years) the lake had lost 28 feet. Naturally this had dried vast tracts of country, many of which we tried to cross, but found it hopeless, owing to elephant spoor 18 inches deep, now hard baked and grassed over, forming death-traps to our camels. Enormous herds of game, including topi, zebra, oryx, and Grant's gazelle, covered the hard-baked, flat, dreary-looking country which borders the whole lake on the east side, while rhino were a positive nuisance; of buffalo we only once saw five, halfway down the lake; giraffe were seen at the north end, and again below the south end. Lions seemed plentiful by the spoor all along, but we could not afford to give up time and wait for them. The heat was terrific, and Clarke was unfortunately taken seriously ill with fever, which laid him up for some days. We had several excitements on our march along the lake. A lioness I had crippled suddenly charged down on us while photographing her with a binocular 12 yards off. We all jumped different ways, and she just missed my boy, but caught my best cordite rifle, breaking one trigger off and discharging both barrels. I luckily finished her before further mischief was done. Then four rhino came down to drink at pools close by our camp. They charged among our cows, donkeys, and goats, stampeding the lot. Another day, which nearly proved to all of us our last, we met our last lot of elephant, in dense bush. A cow with baby calf, the worst I ever met, simply hunted the lot of us. Butter and Mohamed hardly know how she did miss them; Whitehouse and his shikaree plunged under a thick bush; while she tossed his second shikaree over a 10-foot bush, and put her foot on Whitehouse's hat and glasses close to where they had scrambled. Then, as to myself, after dodging her twice by a few inches only, I shot her 7 yards off as she charged a third time. We then returned to finish our lunch, agreeing we had all had enough "being hunted" by elephant for one day.

On April 6 we buried the only boy lost on the whole trip. Five starved Galla had joined us six weeks before, asking to work for food, and capital fellows they turned out. This poor fellow got fever badly, and, after being out of his mind fifteen hours, died, so we covered him over with brushwood, and heaped stones above. We had a heavy roll of sick men all along the lake; it took all our extra mules, donkeys, and ponies to get them along, crossing endless dry river-beds, which in the rains must carry an enormous bulk of water down into the lake. Our whole journey was in sight of the lake, excepting April 10 to 13 , when we passed east of the mountains, the streams still running into the lake. On the 14 th we came to a small fishing village, Burkeneji, and, seeing figures moving about, hoped to have speech with them, but before we arrived they had embarked all their chattels 
on board five dugouts, and stood out to sea! Two days more brought us opposite a huge mountain called Kulab. We stayed here a day so that my companions might go and hunt for big koodoo; Butter had fine luck, bringing back a perfect beauty, horns $52 \frac{1}{8}$ inches. I in the mean time had been prospecting our road ahead. Next day my mule, "Oom Paul," quite eclipsed its former achievements by galloping away down a rocky precipice, over which we both got a toss. I was at the time snapping a photo of the lake with my binocular, which the fall smashed in two-bad luck, as it fogged and spoilt the plates on which I had taken the lioness charging. On April 19, when abreast of Teleki's volcano, we bade farewell to that vast sheet of water, not without a certain regret, I own; at this point we struck Lord Delamere's old track, and by what we had done I could realize the task he had performed. Of course, much rock-moving had to be done, but we had the line of the road, which was a great help. On reaching Mount Nyirobuk, we encountered the Boma and a tribe called Lokuba. Clothing was quite dispensed with; slitting the ear, they insert a large round piece of wood, or some swells prefer four brass cartridge-cases. Hairdressing is practised in many styles, some having it down to their waist, but small curls smeared and plastered down with a red brick-dust looked best. They wear iron armlets and beads, live by hunting, and use bows and poisoned arrows, with long spears. The next tribe, called Semirides, own large flocks of sheep and cattle. They are a wellbuilt and good-looking race.

Passing through the Narrow valley, which contains splendid grass, but few inhabitants, we again got some heavy hill work-April 29, 7250 feet; April 30, 8400 feet-and began to have heavy rains, which made us anxious to push along. On May 3 we travelled across what years ago had been a huge lake running right up to the foot of the range of mountains to the east. On May 6 we saw the lofty peaks of Mount Kenia, some 90 miles distant, glistening in the sunshine. On the following day we had a lovely view of Lake Baringo stretched below us, and a steep climb we had getting down, then several deep and swampy rivers intervened before we brought up at a large prosperous village, called Nyems, 3300 feet. We found here a Swahili trader, who volunteered as guide to Naivasha. On May 11 I killed my last rhino, and the same afternoon we camped at Elmolo, on the main road from Uganda to Mombasa, and what a luxury it was to travel once more on a well-kept road, with decent bridges and a telephone wire! At this point Clarke gave up any further surveying work, the rest being well known. On May 13 we reached Lake Naivasha, where several English people connected with the railway kindly entertained us. Pushing on, we reached Railhead on May 15, having done 103 miles from Lake Baringo in four and a half days-a fine performance, after our camels had done 1453 miles at an average of $11 \frac{1}{2}$ a day. I consider we had wonderful 
luck with our animals; for owing to the enormous amount of rice we carried for the boys, they were heavily loaded. Our losses were thirty camels, two-thirds being entirely due to the poisoning episode; one pony, from horse-sickness; one pony and one mule ran away and got lost; one donkey eaten by lion, and one shot, being lame. We sold all our live stock at Railhead, the railway buying the mules, while Indian traders took our camels. It was with great regret we said good-bye to those best and most long-suffering of animals, which had shared our ups and downs through so many months-one camel having carried a 280-lb. load of rice through from Zeila without a break, which our boys said, was an unheard-of performance. Knowing the difficulties we met with on account of rains, the awful mountain ranges to cross, the never-ending fear of poison, want of any feed the first two months, with the endless marching, and last, but by no means least, sore backs, one can only say it was almost a miracle to get through. We quite expected to be able to replenish our transport both among the Borana people north of Rudolf, or, if south, from the Rendili; but, alas! all these supplies had vanished.

I cannot close this paper without once more calling attention to the splendid work done by our Surveyor, Donald Clarke; no day was long enough for him, and no mountain too high to be climbed, after ever such a long weary march and in the heat of the day. One feature we particularly admired was, he never would insert a yard of country unless seen by himself or vouched for by one of us. When in camp his kind cheery manner endeared him to all, while his skill in doctoring was only equalled by his skill in the cooking line. It is owing to his absence on the West Coast of Africa that the error of the chronometer, before mentioned, cannot be rectified in time to publish the portion of his work beyond Lake Rudolf.

Taking the first train, we duly reached Mombasa, where we shipped all our boys direct to Aden, we ourselves having, on account of the plague at Aden, to go home viâ India, a month's longer journey. Excepting Clarke, none of us had a day's illness; but on the steamer, when close to India, we all had a touch of fever.

\section{THE NATIONAL ANTARCTIC EXPEDITION.}

T'He sailing of the Discovery from Cowes on August 6 marks the successful close of the first stage in the great undertaking which has more or less occupied the minds of geographers in this country for the past eight years. Since November, 1893, the supporters of the proposal for the renewal of antarctic exploration, among whom our President, Sir Clements Markham, has from first to last been the moving spirit, have 


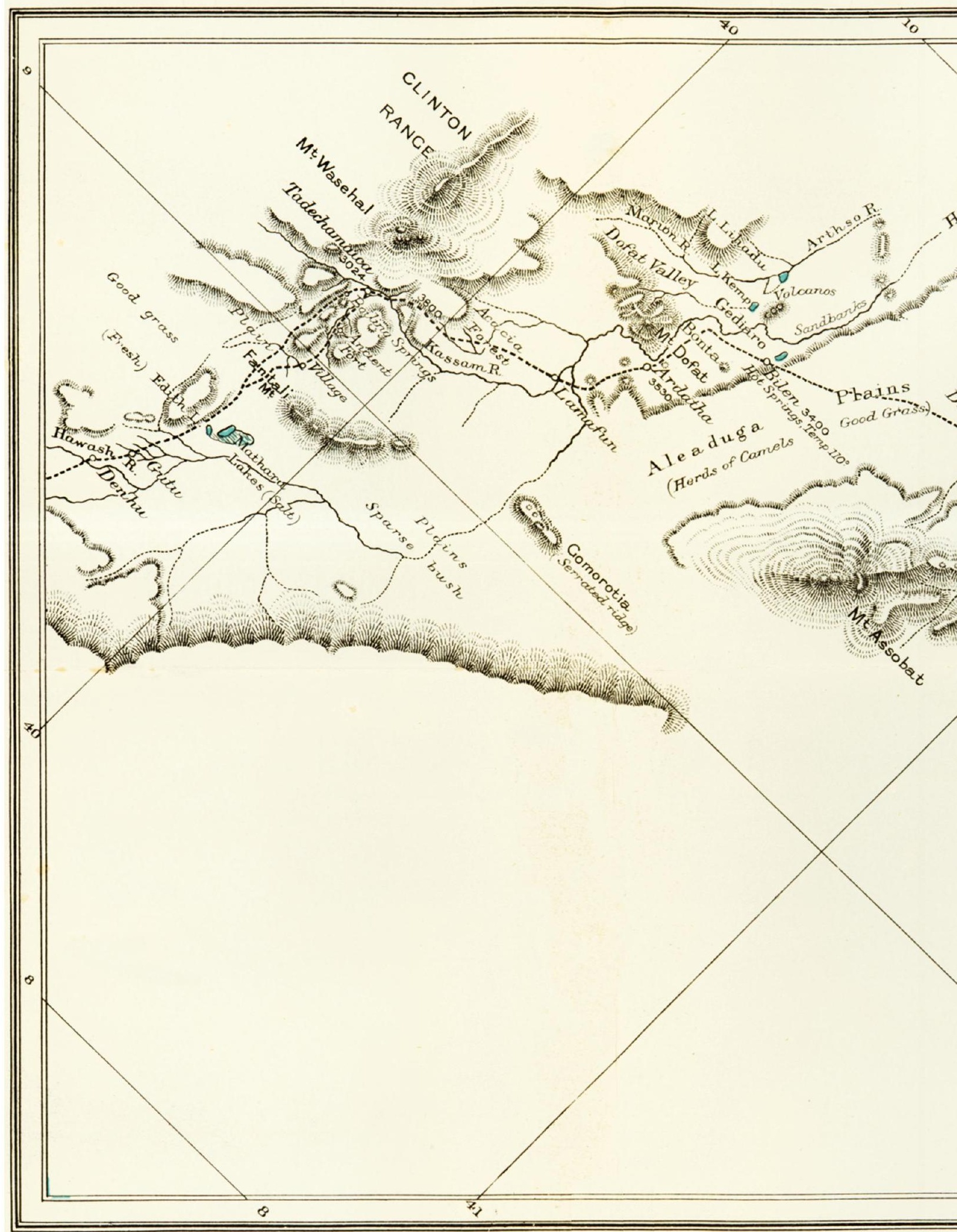




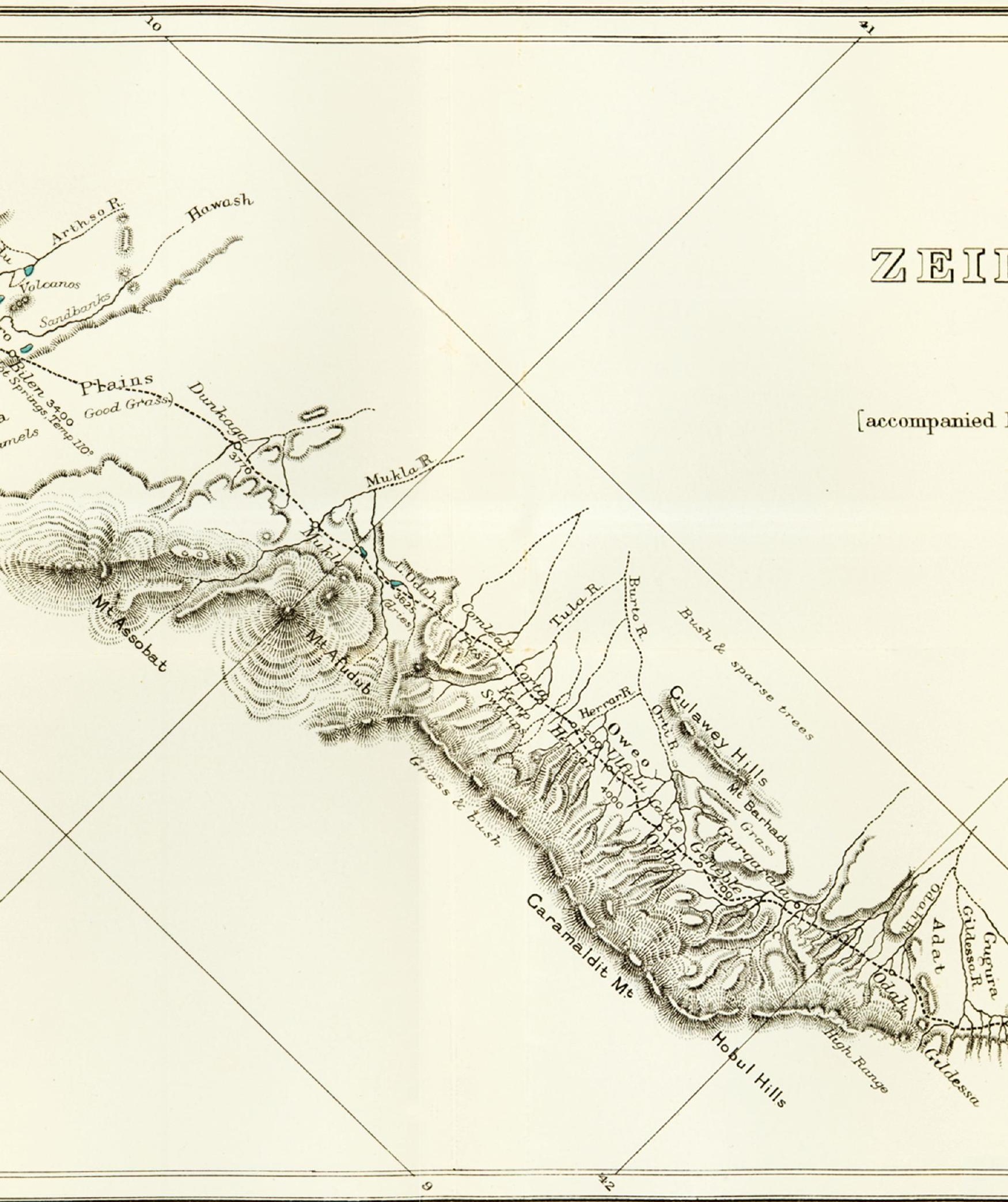




\section{$\mathrm{M} \mathbb{A} \mathbb{P}^{P}$}

to illustrate a journey from

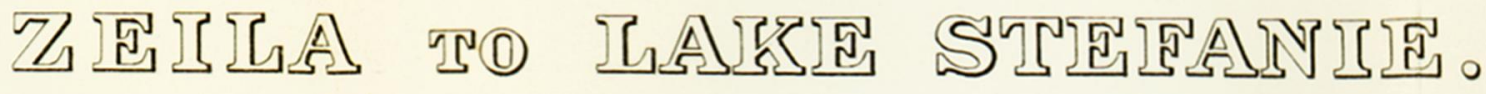

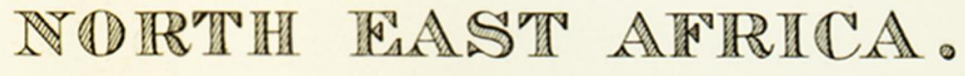

\section{JAMES J.HARRISON.}

[accompanied by Mess.rs A.E.Butter, W. F. Whitehouse \& P.G.Powell-Cotton.] 1899-1900.

Seale of Miles.

$\frac{\text { Natural Scale, } 1: 1.000 .000 \text { or } 15 \cdot 78 \text { miles }=1 \text { inch. }}{20}$

Houghts in peet.

This Map is based on a Survey by Sergeant D. Clarke, R.E., who accompanied Mr. Harrison's expedition as Surveyor.

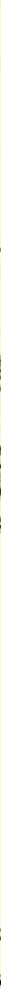




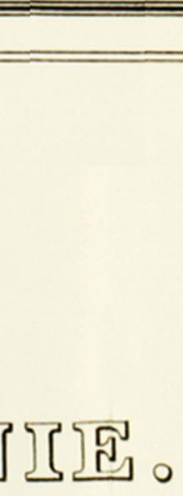

$$
x^{2}
$$

$\sqrt{2}$

Cotton.]

or
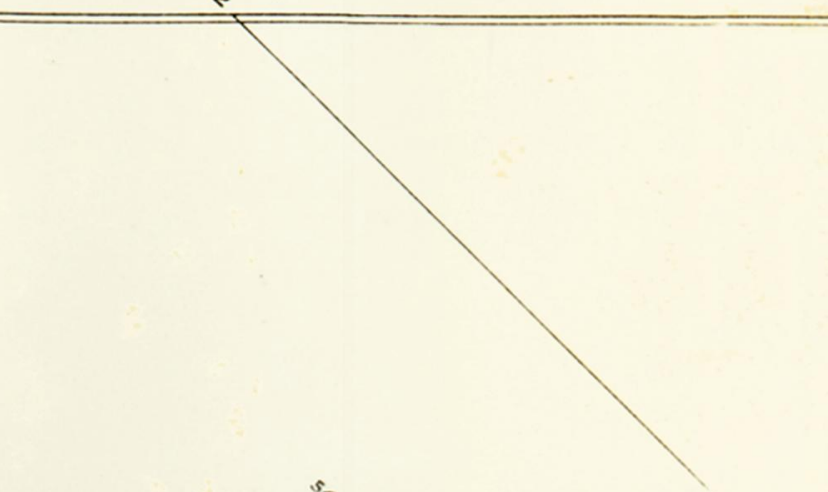


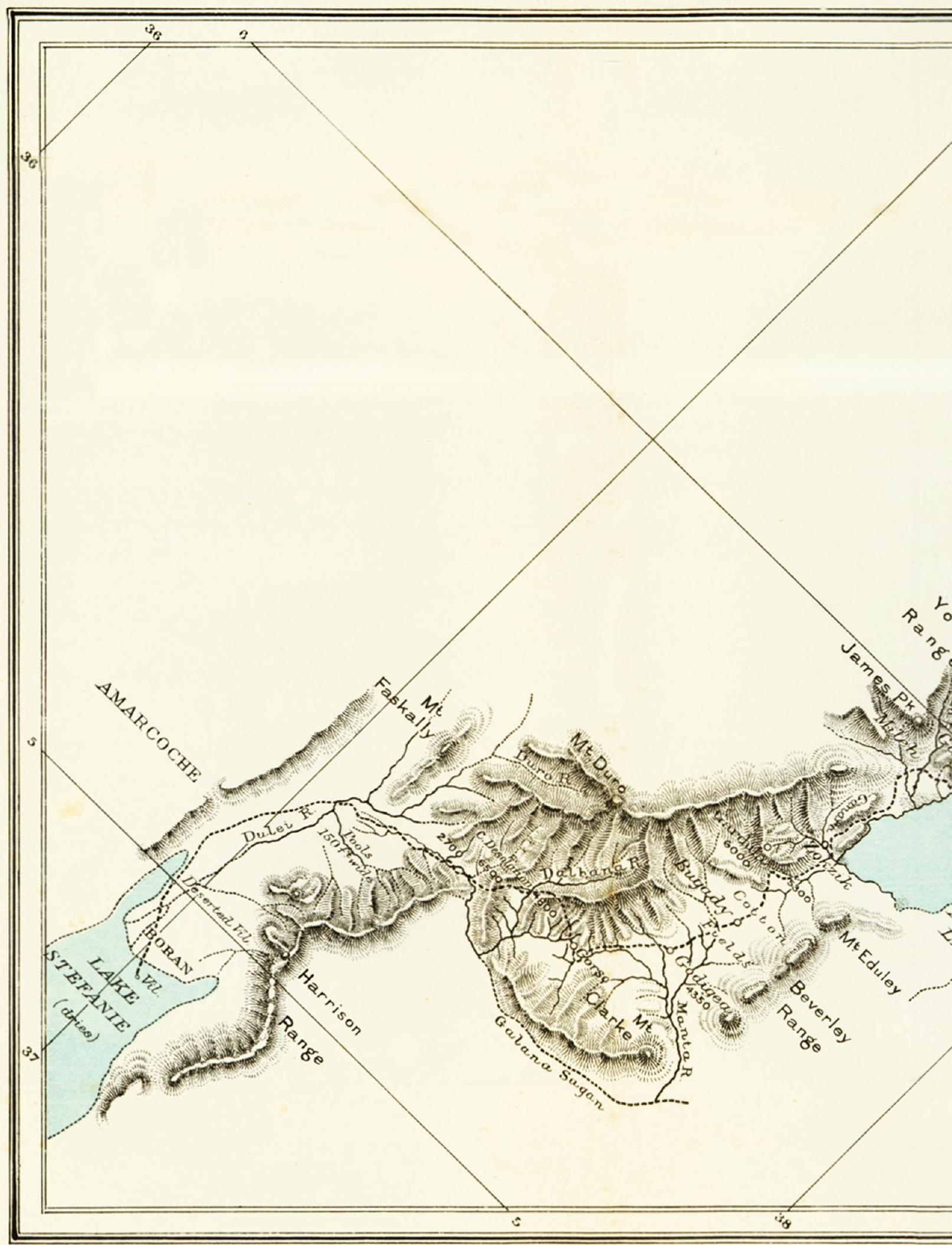




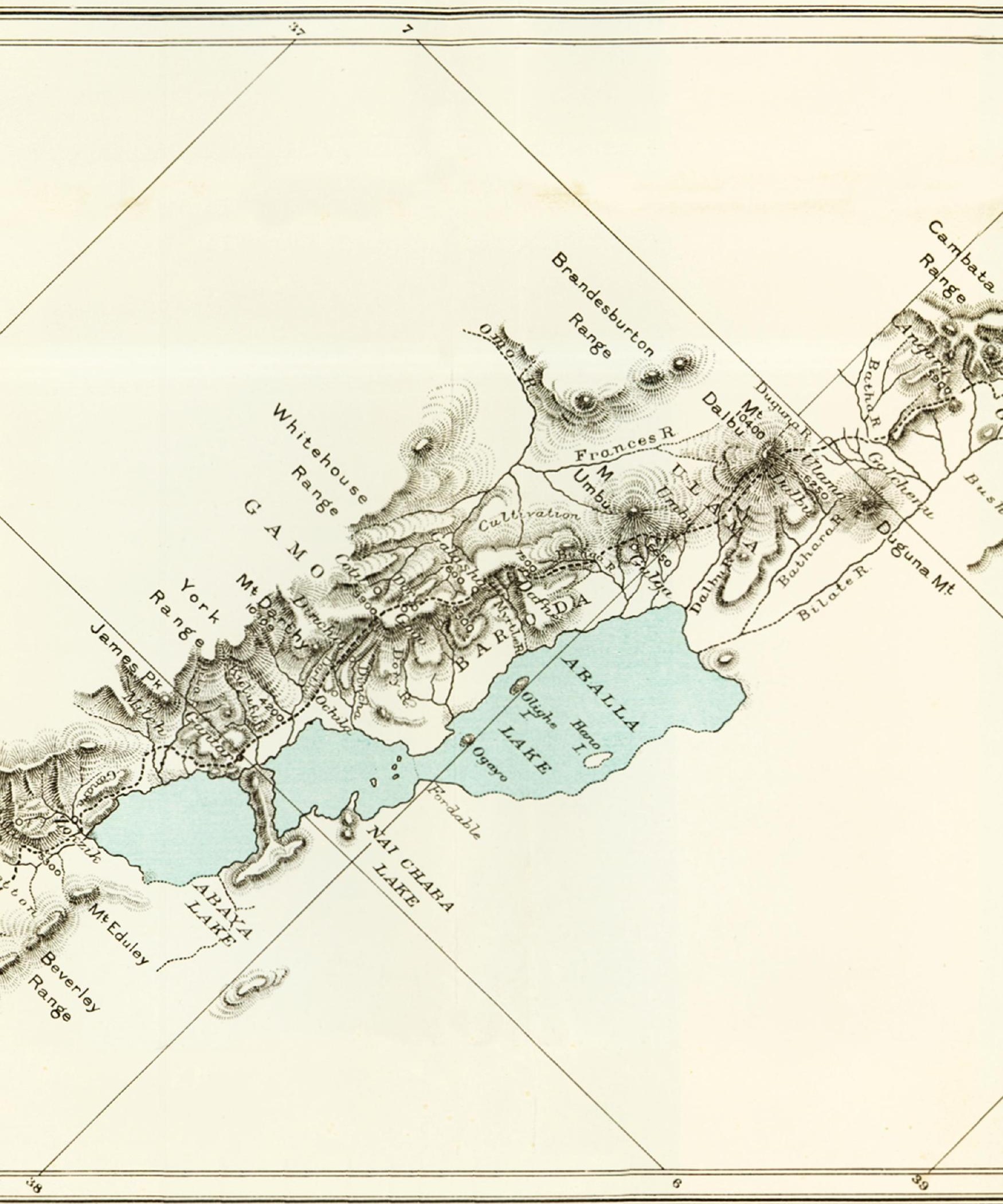

Published by tho Royal Geograph 


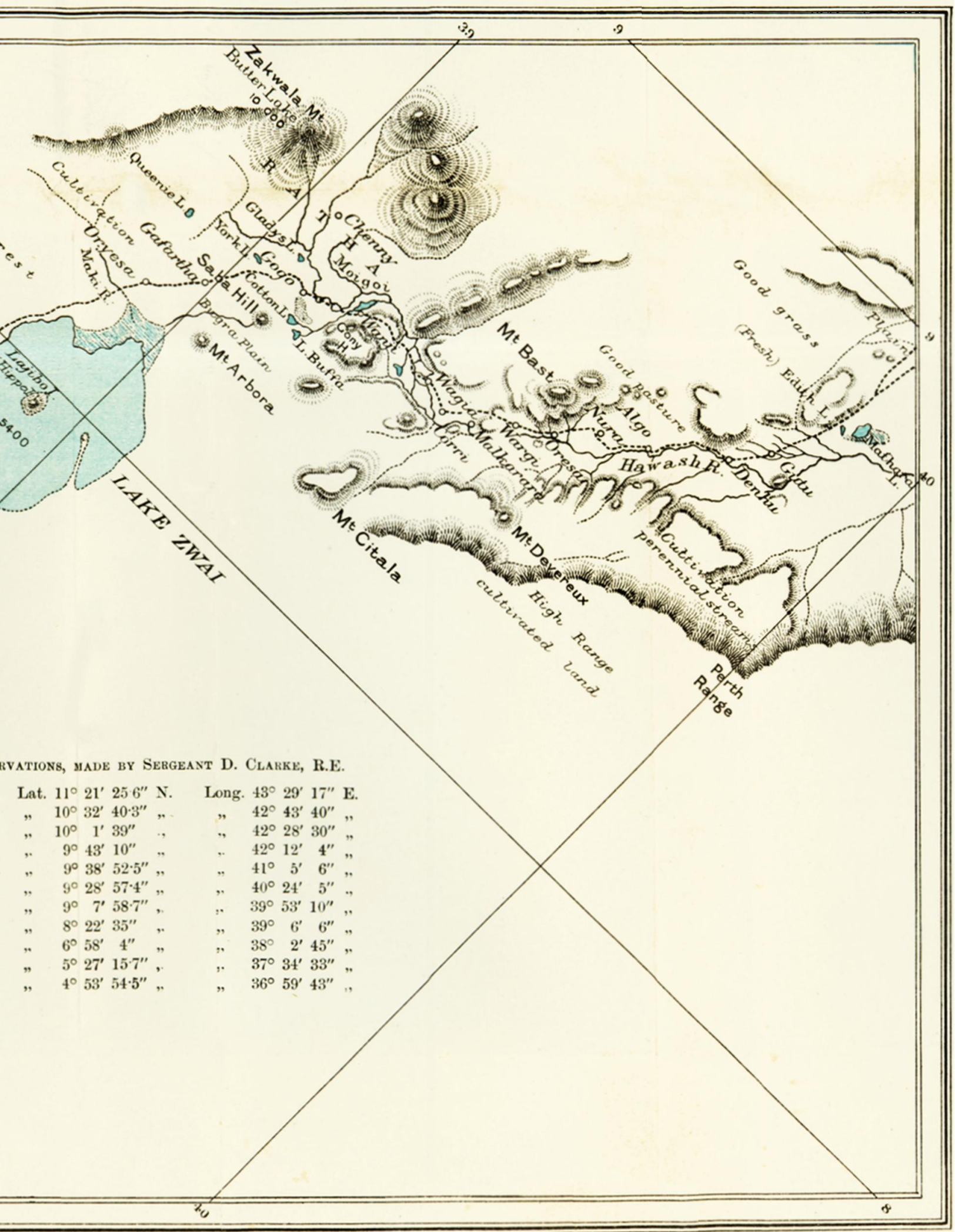

